\title{
BACTERIAL ISOLATES OF MARINE COAST AS COMMERCIAL PRODUCER OF PROTEASE
}

\author{
${ }^{1}$ S. Das, ${ }^{1}$ I. Mukherjee, ${ }^{2}$ M. Sudarshan, \\ ${ }^{3}$ T.P. Sinha, ${ }^{4}$ A.R. Thakur and ${ }^{1}$ Shaon RayChaudhuri \\ ${ }^{1}$ Department of Biotechnology, West Bengal University of Technology, \\ BF-142, Sector-I, Saltlake, Kolkata-700064, India \\ ${ }^{2}$ Inter University Consortium, Sector-III/Plot LB-8. Bidhan Nagar. Kolkata-700098, India \\ ${ }^{3}$ Bose Institute, 93/1, Acharya Prafulla Chandra Road. Kolkata-700009, West Bengal, India \\ ${ }^{4}$ RCM BioSolutions Private Limited, A-101, Green Woods Premium, \\ Kaikhali, Shibtala, Kolkata-700136, West Bengal, India
}

Received 2012-07-30, Revised 2012-08-02; Accepted 2012-08-04

\begin{abstract}
The objective of this work was to explore and exploit the extracellular protease secreting marine microbial biodiversity of the eastern coastal region of India. Culture dependent method was applied for isolation of microbes from the marine coast of West Bengal (Digha and Mandarmani) and Andhra Pradesh (Vizag) in India. Six protease secreting isolates were screened using casein hydrolysing property as well as azocasein assay and characterized on the basis of their morphological, biochemical, physiological and $16 \mathrm{~S}$ rDNA based molecular properties. The enzymes were used for various commercial applications at a laboratory scale. Besides milk media and Luria Bertini broth, all the isolates grew in carbon minimal salt medium with jaggeri or tamarind as the carbon source $(0.3 \% \mathrm{w} / \mathrm{v})$. They showed intracellular metal accumulation when grown in presence of metal salts in the medium as evident from Energy Dispersive Xray Fluorescense Analysis (EDXRF) data. Maximum accumulation of lead was found in case of Bacillus cereus SM2. It showed equal efficiency of metal removal from solid strip at zero valent state. The isolates were also capable of complete removal of silver from exposed X-ray film after $48 \mathrm{hrs}$ of incubation except for Escherichia coli SD1. Bacillus cereus SM2, isolate SD2 (closest to Bacillus pumilus) and isolate SV1 (closest to Bacillus cibi) were able to enhance the cleaning efficiency of detergent when used as additive. Use of tamarind and jaggeri as carbon source in minimal medium would make the process cost effective during large scale application. The ability to grow in a wide range of temperature and $\mathrm{pH}$ and accumulation of heavy metals revealed that these isolates would be potential candidates for bioremediation. Thus the marine diversity for protease production is extremely rich with immense commercial applications.
\end{abstract}

Keywords: Marine Coast, Protease, Bioremediation, Degumming, Detergent-Addtive

\section{INTRODUCTION}

Bacteria were isolated and cultivated from all possible regions of the earth, on the basis of their habitat, diversity, ecological functions, degree of pathogenicity and biotechnological applications. $70 \%$ of the earth's surface is covered by oceans with rich microbial diversity. About $3.6 \times 10^{29}$ microorganisms were found in marine environments, including subsurface and harbour (Sogin et al., 2006).

Marine microbes are now being looked upon as a potential source of various compounds; pharmaceutical, nutritional supplements, agrochemicals, cosmetics and enzymes (Vignesh et al., 2011; Baharum et al., 2010). However compounds from marine sources are often available only in low quantities and hampers their further processing into commercial products (Haefner, 2003). Bioactive screening has also focused on microorganisms associated with such host surfaces and the various natural products isolated from marine invertebrates often show structural similarities to known metabolites of microbial origin (Arpigny and Jaeger, 1999; Haygood et al., 1999). The basic characteristics of the enzymes derived from the marine sources differ from their

Corresponding Author: Shaon RayChaudhuri, Department of Biotechnology, West Bengal University of Technology, BF-142, Sector-I, Saltlake, Kolkata-700064, India 
terrestrial counterparts due to their natural habitat. Marine microbial enzymes are reported to be more stable and active than those originating from plant and animal sources since they possess almost all characteristics desired for their biotechnological applications (Bull et $a l .$, 2000). Enzymes like protease, lipase, amylase and cellulase have immense industrial demand. Some of the marine microorganisms have enzymes which hydrolyze the polysaccharides like lignin, alginate, agar, cellulase, carrageenan and xylan (Andrykovich and Marx, 1988). They are used in biodegradation, e.g.,: Bacillus cereus, Bacillus sphericus, Vibrio furnisii and Brevundimonas vesicularis are reported to hydrolyze nylon 6 and nylon 66 (Sudhakar et al., 2007). Two $\gamma$-proteobacteria; Alcanivorax and Cycloclasticus play an important role in petroleum hydrocarbon degradation posing to be potential candidates for bioremediation at oil spill sites (Harayama et al., 2004). Bacteria attached to the environmental surface by adhesion commonly live as biofilm. Gram positive bacteria like Staphylococcus aureus, Bacillus subtilis and Gram negative organism like Pseudomonas aeruginosa, Escherichia coli are attached to the surface with help of EPS (Karunakaran and Biggs, 2011). Biofilm have both positive and negative impact on normal life, as well as at industrial scale. Biofilm formation helps in remediation of waste water in a bioreactor, degradation of recalcitrant, aquaculture, whereas the formation of biofilm in heat exchanger, pipeline, ship surface, medical and industrial device causes major problem (Kwon et al., 2002).

Among all the enzymes, protease dominate the world enzyme market with $60 \%$ market share (Rao et al., 1998), 40\% of which is of microbial origin (Godfrey and We, 1996). In various industrial sectors, extracellular proteases have multiple applications such as detergent additives (George-Okafor and Odibo, 2011; Kumar et al., 2008; Malathu et al., 2008); in cheese making, baking, preparation of soya hydrolysates and meat tenderization (Rao et al., 1998); extraction of metallic silver from used X-ray films (Gupta et al., 2002), cleaning of contact lenses (Power et al., 2009), degumming of coccon fiber (Arami et al., 2007); in leather industry for soaking, dehairing and bating to avoid pollution caused due to conventional methods (Tork et al., 2010; Hameed et al., 1999).

The coastal areas are getting increasingly polluted by domestic, commercial, agricultural and industrial pollutants. The metal contamination of sea water is mainly due to discharge of the chemical load from various industries into the rivers and from the rivers to the sea. Some of the metals like cadmium, arsenic, lead and mercury are toxic in nature. As per reported literature, heavy metals like zinc, copper, nickel, chromium, mercury, cadmium, cobalt, lead and arsenic were found in the coastal regions of the Bay of Bengal
(ftp://ftp.fao.org/docrep/fao/007/ad894e/AD894E06.pdf). The metal accumulating $(\mathrm{Cu}, \mathrm{Cd}, \mathrm{Ni}, \mathrm{Vd})$ property of some marine bacteria make them potential sources for bioremediation (De et al., 2006; Miranda and Rojas, 2006). Bacterial isolates from marine waters demonstrated varying degrees of resistance to antibiotics like Chloramphenicol, ampicillin, streptomycin, tetracycline and kanamycin (Manivasagan et al., 2011; Souza et al., 2006). Certain bacterial isolates from marine coast of West Bengal have already been isolated and characterized.

The focus of this study is on isolation and characterization of protease producing marine bacteria for bioremediation with the long term goal of industrial applications.

\section{MATERIALS AND METHODS}

\subsection{Site of Isolation}

Water samples were collected from the coastal regions of Digha and Mandarmani in West Bengal and Vizag in Andhra Pradesh, India to screen for extracellular protease producing microbes. The collection was done in plastic containers and transferred to laboratory at room temperature and the process of isolation was initiated immediately.

\subsection{Cultivation Medium and Growth Conditions}

Since the objective was to isolate extracellular protease secreting bacteria, milk medium plates were used as selective media (Adarsh et al., 2007). $50 \mu \mathrm{L}$ of water sample collected from the different sites were directly spread on the milk media plates and incubated at $37^{\circ} \mathrm{C}$ for overnight. Repeated streaking on LB agar was adapted for isolation of pure culture. The maintenance and characterization of the pure isolates was carried out in LB medium whereas the substrate profile was carried out using substrate strips (Himedia Carbohydrate kit, Code No. KB009) as per manufacturers protocol as well as in carbon minimal salt medium using different substrates.

Unless mentioned specifically, the general culture condition was maintained at $37^{\circ} \mathrm{C}$ with shaking at 150 rpm.

\subsection{Morphological Characterization}

The initial identification of the pure isolates was on the basis of their morphology using light microscopy (1000X magnification on a Zeiss Axiostar Plus microscope) as well as Environmental scanning electron microscopy (FEI QUANTA 200 MARK 2 at $15 \mathrm{kV}$ ) (Adarsh et al., 2007). The Gram nature of the isolate was determined by differential staining as per standard procedure. It was reconfirmed through Real-time PCR as 
reported by Shigemura et al. (2005). Endospore, capsule as well as acid-fast staining was performed using standard protocol followed by observation under a Zeiss Axiostar Plus microscope.

\subsection{Biochemical Characterization}

The isolates were checked for their ability to produce enzymes like DNase, oxidase, lipase, lecithinase, catalase and amylase. The tests for the first five enzymes were done according to the protocol. The amylase test was done on 3\% starch agar plate and incubated at $37^{\circ} \mathrm{C}$ for overnight followed by addition of iodine solution to the plate.

\subsection{Physiological Characterization}

The optimum $\mathrm{pH}$ and temperature for bacterial growth, growth kinetics and utilization of different substrates as carbon sources was done according the protocol. The biofilm forming ability was checked following the protocol of O'Toole and Kolter (1998).

\subsection{Antibiotic Assay}

The response of the isolates towards 18 different antibiotics (HiMedia) was checked according to the procedure reported.

\subsection{Heavy Metal Tolerance}

The Minimum Inhibitory Concentration (MIC) for metal salts; $\mathrm{AgNO}_{3}, \mathrm{Al}\left(\mathrm{NO}_{3}\right)_{3} .9 \mathrm{H}_{2} \mathrm{O} \quad \mathrm{CdSO}_{4} .8 \mathrm{H}_{2} \mathrm{O}$, $\mathrm{CoCl}_{2} \cdot 6 \mathrm{H}_{2} \mathrm{O}, \mathrm{Cr}_{2} \mathrm{O}_{3}, \mathrm{CuSO}_{4} \cdot 5 \mathrm{H}_{2} \mathrm{O}, \mathrm{FeSO}_{4} \cdot 7 \mathrm{H}_{2} \mathrm{O}, \mathrm{HgCl}_{2}$, $\mathrm{NiCl}_{2} \cdot 6 \mathrm{H}_{2} \mathrm{O}, \quad \mathrm{Pb}\left(\mathrm{NO}_{3}\right)_{2}$ and $\mathrm{ZnSO}_{4} \cdot 7 \mathrm{H}_{2} \mathrm{O}$ were determined as per the protocol of Adarsh et al. (2007). Among the eleven metal salts checked for MIC determination, the intracellular accumulation using EDXRF analysis (Adarsh et al., 2007) (Jordan Valley EX 3600 EDXRF system) was carried out only for treatment with common environmental contaminants like $\mathrm{Cu}, \mathrm{Cr}$, $\mathrm{Co}, \mathrm{Ni}$ and $\mathrm{Pb}$.

\subsection{Molecular Characterization}

The DNA extracted from the pure isolates was used for PCR amplification of 16S rDNA gene (RayChaudhuri and Thakur, 2006). The PCR product was sequenced using ABI (Applied Biosystems) partial sequencing kit. The sequences were subjected to BLAST analysis. The novel sequences were submitted to GenBank and phylogenetic tree was constructed using neighbour joining method.

\subsection{Continuous Production of Enzyme by Immobilization on Inert Matrix}

Enzyme (amylase and protease) from isolate SV1 were used as additive along with other enzymes to detergent for cleaning efficiency enhancement
(RayChaudhuri S, Novel indigenous sources of enzymes as detergent additives, Indian Patent No 599/KOL/2010 dt June 1 2010; PCT/IB2010/001816 dt July 24, 2010; U.S. Patent Application No.-13/126,109 dt 26-April 2011). To get the continuous supply of enzymes, SV1 was immobilized on two type of inert matrices; corrugated sheet as well as hay. Protease was estimated by azocasein method as reported by Malathu et al. (2008) and amylase production was calculated by DNS method as reported by Anto et al. (2006). Enzyme production at regular intervals of $1 \mathrm{~h}$ was compared for immobilized matrix (hay as well as sheet) and shake flask culture (incubated at $37^{\circ} \mathrm{C}$ with continuous shaking at $150 \mathrm{rpm})$.

\subsection{Application of Crude Extracellular Protease}

The extracellular protease from all isolates were checked for different applications; removal of metal from zero valent state, removal of silver impregnated in gelatin layer on exposed X-ray film and wash performance analysis.

\subsection{Recovery of Precious Metal}

Silver is impregnated within the gelatin layer of $\mathrm{X}$ ray film. The strain with gelatinase activity could be used for recovery of silver. To check the ability of the strains under the current study, $1 \times 1 \mathrm{~cm}^{2}$ exposed X-ray films were incubated with 0.2 units of enzyme for $48 \mathrm{~h}$ at room temperature. Proteinase K ( 0.2 units) was considered as the standard protease under the same conditions whereas distilled water was taken as the negative control.

Considering the heavy metal accumulating ability of SM2, the impact of the strain on metal strips (zero valent state) of silver $(\mathrm{Ag})$ and gold $(\mathrm{Au})$ was tested. $1 \%$ inoculum of overnight grown SM2 was added to $3 \mathrm{~mL}$ of $\mathrm{LB}$ in tubes and incubated at $37^{\circ} \mathrm{C}$ at $150 \mathrm{rpm}$ for overnight. Next Day, the silver $\left(0.7 \times 0.8 \mathrm{~mm}^{2}\right)$ and the gold strip $\left(0.9 \times 0.8 \mathrm{~mm}^{2}\right)$ were dipped into two different sets of SM2 culture and $1 \mathrm{ml}$ of $1 \mathrm{X} \mathrm{LB}$ was added to the respective tubes. To sustain their growth, $1 \mathrm{ml}$ of $1 \mathrm{X}$ LB medium was replaced every $12 \mathrm{~h}$ retaining the cells in each tube. This condition was maintained for 2 months. $10^{9}$ cells from each condition were harvested, washed with $0.1 \mathrm{~N} \mathrm{HCl}$ thrice followed by Phosphate Buffered Saline (PBS) thrice and finally resuspended in PBS. A second set of gold and silver strip treated cells was prepared by washing with only PBS. Both of these sets were analyzed using EDXRF. The strips were taken out from the respective tubes. The treated and control strips (untreated) were then washed with distilled water, incubated in $1 \mathrm{~mL}$ bleach for $15 \mathrm{mins}$ and again washed with distilled water thrice before drying. The surface of the strips was observed by SEM (FEI QUANTA 200 MARK 2 at $15 \mathrm{kV}$ ) analysis. 


\subsection{Wash Performance Analysis}

Wash performance analysis was performed using extracellular protease from individual isolates as per the protocol of Malathu et al. (2008). Among the six isolates, extracellular protease from isolate SM2 showed better cleaning efficiency (data not shown). To optimize the enzyme formulation for cleaning efficiency enhancement, two combinations were worked out. $3 \mathrm{~mL}$ cell free supernatant (SD2/SD4) as lipase sources was added to $6 \mathrm{U}$ protease from SM2 per gram of detergent. Wash performance for these two combinations were tested for stained cloths post washing and drying using densitometric scanning [Molecular analyst (BIORAD)] and the efficiency was expressed as percentage of stain removed.

\subsection{Market Survey}

As per the densitometric scanning data, the combination of SM2+SD2 was further selected for market survey. Cell free supernatant containing extracellular protease and lipase were concentrated by lyophilization. Each gram of detergent was mixed with $6 \mathrm{U}$ protease as well as $2.25 \mathrm{U}$ lipase and air dried. The detergent with and without additive were then supplied to 50 different household to get a feedback on the wash performance efficiency as per the supplied questionnaire.

\section{RESULTS AND DISCUSSION}

\subsection{Isolation of Bacterial Strains}

Five isolates were obtained with clearing zone around the colony due to casein degradation. Four were isolated from West Bengal marine coast. SM2 was isolated from water of Mandarmani coastal region whereas SD2, SD3 and SD4 were isolated from Digha coast. SV1 was isolated from Rishikonda coastal water (Vizag) in Vishakhapatnam andhra Pradesh, India. SD1, non-casein degrading strain was isolated from Digha coast.

\subsection{Characterization of the Isolates}

SM2 was diplobacilli; SD1, SD2 and SD4 were bacilli while SD3 and SV1 were bacilli in chain. The Gram nature was also reconfirmed by the Real time PCR based detection method. Except SD1 all other isolates were gram positive while only SD1 showed presence of capsule. One of the important facts observed was the presence of endospores in all the isolates; this finding can be correlated with their survivability in the extreme condition of a marine environment. They all were negative for acid fast staining. They were all catalase and oxidase positive (Table 1). These two enzymes were reported to have important functions in defence system of an organism, supporting the survivability under adverse conditions. The presence of enzymes like DNase could be important in host prey interaction thus defending the organism. Presence of enzymes like amylase, lipase and protease (Table 1) would be important from the point of application in detergent, leather, pharmaceutical and many other industries. The biochemical characteristics of the isolates were listed in Table 1. To check its protease producing status azocaesin assay was performed using cell free supernatant from each isolate. The result showed extracellular protease activity in case of each isolate in the following descending order of production: SD1 $(10.23 \pm 0.381 \mathrm{U})$, SM2 (3.425 $\pm 0.106 \mathrm{U})$, SD2 (3.275 $\pm 0.318 \mathrm{U})$, SD4 $(2.8 \pm 0.283 \mathrm{U}), \mathrm{SD} 3(2.4 \pm 0.141 \mathrm{U}), \mathrm{SV} 1 \quad(2.325 \pm 0.247$ U). This clearly indicated that the method used for analyzing protease at the qualitative level was insensitive for the enzyme produced by isolate SD1. The method of plate clearing reveals only caesinase activity. Any other protease activity would go unnoticed using this method. Scanning Electron microscopy revealed pilli like structure between two or more cells for quite a few isolates (Fig. 1a-f). This structure allows the stacking pattern of cells which are reported in many groups of bacteria (Sattley et al., 2008).

The $\mathrm{pH}$ profile for isolates indicated that all the isolates except SD1 could tolerate $\mathrm{pH}$ variation in the range of 6-12. Isolate SD1 was found to grow in a wider range of $\mathrm{pH}$ from 4-12. The optimum $\mathrm{pH}$ was at 7 for isolate SM2 and SD1; 7.5 for SD3 and SV1 and 8.5 for SD2 and SD4. Similar condition was observed for the temperature adaptation; the isolates were found to grow in a range between $20-40^{\circ} \mathrm{C}$. The optimum temperature was $30^{\circ} \mathrm{C}$ for isolate $\mathrm{SM} 2$ and $\mathrm{SD} 3 ; 37^{\circ} \mathrm{C}$ for SD1, SD2 as well as SV1 and $40^{\circ} \mathrm{C}$ for SD4. This adaptation was an indication for their survival under different environmental conditions and thus their implementation in various aplications.

Variation in growth in the presence of different substrates were observed. Maximum growth was observed in LB followed by Tamarind and Jaggery. The later two were used as cheaper sources compared to conventional media for large scale growth thus making the process cost effective during large scale applications. They were able to utilize different carbohydrates for their growth (Table 1).

All of the strains showed good biofilm forming ability from the initial day, except for SM2, SD4 and SD1. The biofilm forming ability of SD1, SM2 and SD4 were observed from 2nd, 4th and 5th day onwards respectively (Fig. 2) using standard crystal violet staining method followed by optical density measurement at $620 \mathrm{~nm}$. The biofilm forming ability would help in their usage in packed bed bioreactors for bioremedial as well as enzyme production purposes. 
Table 1. Detailed characterization of the six isolates under optimal conditions of growth

\begin{tabular}{|c|c|c|c|c|c|c|c|}
\hline & & SM2 & SD1 & SD2 & SD3 & SD4 & SV1 \\
\hline \multirow{4}{*}{$\begin{array}{l}\text { Morphological } \\
\text { characterization }\end{array}$} & Gram Nature & + & - & + & + & + & + \\
\hline & Endospore staining & + & + & + & + & + & + \\
\hline & Capsule staining & - & + & - & - & - & - \\
\hline & Acid Fast staining & - & - & - & - & - & - \\
\hline \multirow{7}{*}{$\begin{array}{l}\text { Biochemical } \\
\text { characterization }\end{array}$} & Protease & + & - & + & + & + & + \\
\hline & Lipase & - & - & + & - & + & - \\
\hline & Amylase & + & - & - & + & - & + \\
\hline & DNase & + & - & + & No growth & + & No growth \\
\hline & Oxidase & - & + & + & + & + & + \\
\hline & Catalase & + & + & + & + & + & + \\
\hline & Lecithinase & - & - & - & No growth & - & - \\
\hline \multirow[t]{2}{*}{ Molecular } & GenBank & FJ377719 & $\begin{array}{l}\text { FJ377721 } \\
\text { Sscherichig }\end{array}$ & $\begin{array}{l}\text { FJ377718 } \\
\text { Bacillus }\end{array}$ & FJ377722 & $\begin{array}{l}\text { FJ377724 } \\
\text { (a)rization }\end{array}$ & FJ377723 \\
\hline & $\begin{array}{l}\text { Closest Neighbour } \\
\text { (\% similarity) }\end{array}$ & $\begin{array}{l}\text { cereus } \\
(100)\end{array}$ & $\begin{array}{l}\text { coli } \\
(100)\end{array}$ & $\begin{array}{l}\text { pumilus } \\
\text { (99.09) }\end{array}$ & $\begin{array}{l}\text { cibi } \\
(99.95)\end{array}$ & $\begin{array}{l}\text { Bacillus pumilus } \\
\text { (99.12) }\end{array}$ & $\begin{array}{l}\text { Bacillus cibi } \\
(99.91)\end{array}$ \\
\hline \multirow[t]{2}{*}{ Antibiotics } & Resistant & $\begin{array}{l}\mathrm{A}, \mathrm{Mt}, \mathrm{Tr} \\
\mathrm{Cx}, \mathrm{Pb}, \mathrm{Ca}, \mathrm{R} .\end{array}$ & $\begin{array}{l}\text { Mt, } \mathrm{Cx}, \mathrm{Pb} \\
\text { Va, R. }\end{array}$ & $\mathrm{Mt}, \mathrm{Pb}, \mathrm{Ca}$. & Mt & $\mathrm{Mt}, \mathrm{Pb}, \mathrm{Ca}$ & Mt \\
\hline & Sensitive & T, Cf, Do, G, Nx. & $\begin{array}{l}\text { T, Cf, Do, G, Nx, } \\
\text { C, Ce, Tr, Ca }\end{array}$ & $\begin{array}{l}\text { T, Ce, Cf, Do, A, } \\
\text { Tr, G, Nx, N, R. }\end{array}$ & $\begin{array}{l}\text { T, Ce, Cf, Do, } \\
\text { A, Tr, G, Nx, N, } \\
\text { R, Pb, Ca, Ro, } \\
\text { Cx, C, Cq, Va }\end{array}$ & $\begin{array}{l}\text { T, Ce, Cf, Do, A, } \\
\text { Tr, G, Nx, N, R, Ro, } \\
\text { C, Cq, Va }\end{array}$ & $\begin{array}{l}\text { T, Ce, Cf, } \\
\text { Do, A, Tr, G, } \\
\text { Nx, N, R, Pb, Ca, } \\
\text { Ro, Cx, C, Cq, Va }\end{array}$ \\
\hline Substrate & Carbohydrates & $\begin{array}{l}\text { Maltose, Fructose, } \\
\text { Dextrose, Trehalose, } \\
\alpha \text {-methyl deglucoside, } \\
\text { Esculin. utilization }\end{array}$ & $\begin{array}{l}\text { Lactose, Xylose, } \\
\text { Maltose, Fructose, } \\
\text { Dextrose, Galactose, } \\
\text { Raffinose, Trehalose, } \\
\text { Melibiose, Sucrose, } \\
\text { L-Arabinose, Mannose, } \\
\text { Glycerol, } \alpha \text {-methyl } \\
\text { deglucoside, Rhamnose, } \\
\text { Esculin, D-Arabinose, } \\
\text { Malonate. }\end{array}$ & $\begin{array}{l}\text { Lactose, Xylose, } \\
\text { Maltose, Fructose, } \\
\text { Dextrose, Trehalose, } \\
\text { Melibiose, Sucrose, } \\
\text { L-Arabinose, } \\
\text { Mannose, } \\
\text { Glycerol, Salicin, } \\
\text { Mannitol, Adonitol, } \\
\alpha \text {-methyl deglucoside, } \\
\text { Rhamnose, Cellobiose, } \\
\text { Esculin, D-Arabinose, } \\
\text { Citrate, Malonate. }\end{array}$ & $\begin{array}{l}\alpha \text {-methyl } \\
\text { deglucoside, } \\
\text { Melibiose, } \\
\text { Sucrose. } \\
\end{array}$ & $\begin{array}{l}\text { Fructose, Dextrose, } \\
\text { Trehalose, Sucrose, } \\
\text { L-Arabinose, } \\
\text { Mannose, } \\
\text { Adonitol, } \alpha \text {-methyl } \\
\text { deglucoside, } \\
\text { Rhamnose, } \\
\text { Cellobiose, Esculin, } \\
\text { D-Arabinose, Citrate, } \\
\text { Malonate. }\end{array}$ & $\begin{array}{l}\alpha \text {-methyl } \\
\text { deglucoside, } \\
\text { Esculin. }\end{array}$ \\
\hline
\end{tabular}

Each isolates were grown under its optimal condition and detailed morphological, physiological (antibiotic sensitivity), biochemical as well as molecular characterization (16SrDNA sequence based phylogenetic analysis) were performed. The sequences being novel were submitted to GenBank and the accession numbers were mentioned above. The abbreviations for the antibiotics were as follows: A for Ampicillin, Cq for Cephadroxil, C for Chloramphenicol, $\mathrm{Cx}$ for Cloxacillin, Ce for Cephotaxime, Ca for Ceftazidime, Cf for Ciprofloxacin, Do for Doxycycline Hydrochloride, G for Gentamicin, Mt for Metronidazole, N for Neomycin, Nx for Norfloxacin, Pb for Polymyxin B, R for Rifampicin, Ro for Roxithromycin, $\mathrm{T}$ for Tetracycline, Tr for Trimethoprin, Va for Vancomycin.

\subsection{Growth Profile}

The growth profile determined in enriched medium (LB) indicated that among all the isolates, SM2 and SD1 exhibited more rapid growth with extended logarithmic phase $(8 \mathrm{~h})$ in comparison to others (Fig. 3). The remaining four isolates showed a similar growth pattern with about $5 \mathrm{~h}$ of logarithmic phase.

\subsection{Antibiotic Sensitivity}

The complete profile for sensitivity towards different antibiotics would further help in characterizing the isolates and designating them as distinctly different from one another. Since the future objective of this study would be to use these isolates for bioremedial purpose, it might result in a situation where the released microbes from the bioremediation plant cause adverse health effects among the workers there. The knowledge of antibiotic sensitivity would be important in this context. Table 1 indicates the different responses of the six isolates towards various antibiotics. For some antibiotics like tetracycline, ceftazidime, doxycycline, metronidazole, gentamycin and norfloxacine, the isolates exhibited similar responses which could be due to their common site of origin.

\subsection{Heavy Metal Tolerance}

All the isolates were found to tolerate a wide range of metal salts namely $\mathrm{Al}, \mathrm{Ni}, \mathrm{Pb}, \mathrm{Fe}, \mathrm{Zn}$. Among all isolates, SD1 was found to show maximum tolerance towards the above mentioned metals. An important finding was its Minimum Inhibitory Concentration (MIC) of about $14 \mathrm{mM}$ for $\mathrm{CoCl}_{2} \cdot 6 \mathrm{H}_{2} \mathrm{O}, 11 \mathrm{mM}$ for $\mathrm{FeSO}_{4} \cdot 7 \mathrm{H}_{2} \mathrm{O}$ and $14 \mathrm{mM}$ for $\mathrm{NiCl}_{2} \cdot 6 \mathrm{H}_{2} \mathrm{O}$. All isolates being tolerant to a number of metals, the next step was to find the fate of these metals within the cell. Since the main objective was to apply the isolates for remediation, the primary objective was to investigate their metal accumulating property. For five of the metals viz. $\mathrm{Cr}$, $\mathrm{Cu}, \mathrm{Co}, \mathrm{Ni}$ and $\mathrm{Pb}$, the intracellular accumulation was checked using EDXRF analysis for the six isolates. Here the untreated (normal) cells were taken as negative control in order to assess the intracellular accumulation (Table 2). It was observed that intracellular accumulation of lead was highest in all the isolates as compared to other metals. Copper and chromium were also accumulated in significant amounts in some of the isolates, whereas accumulation of cobalt and nickel was considerably less. 


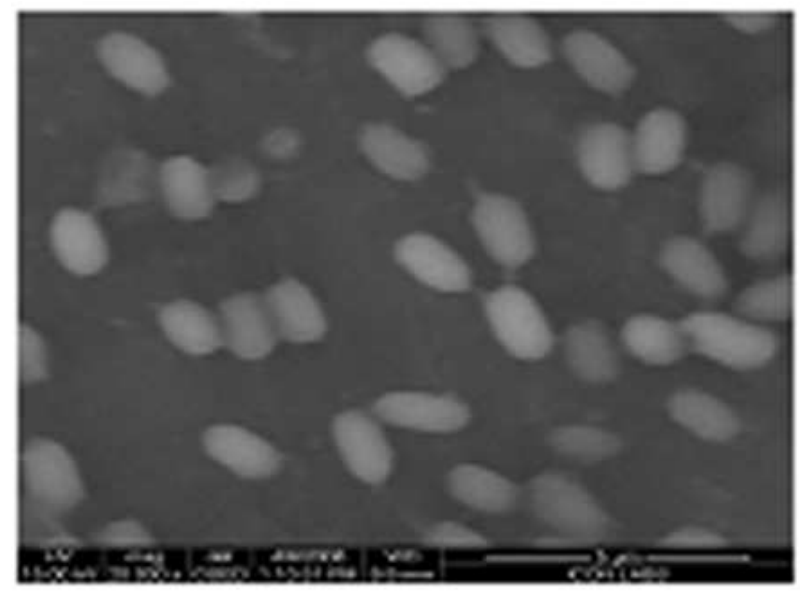

(a)

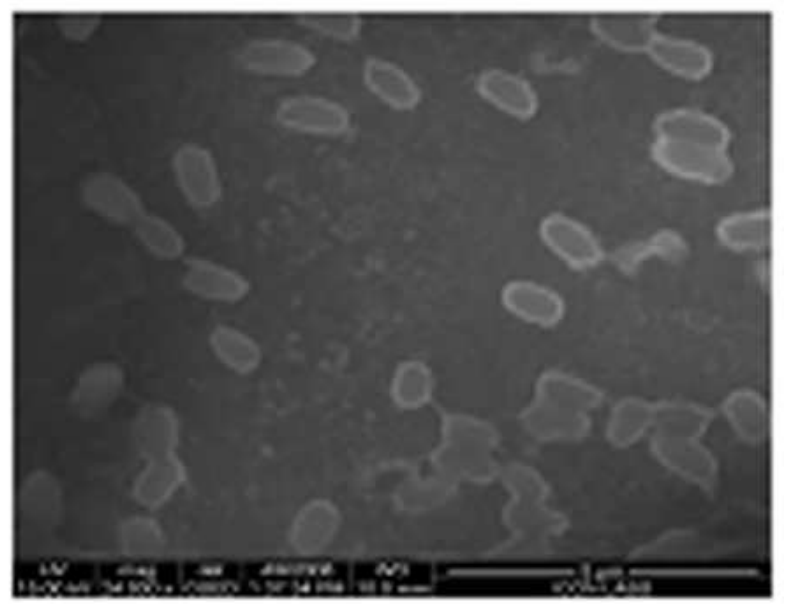

(c)

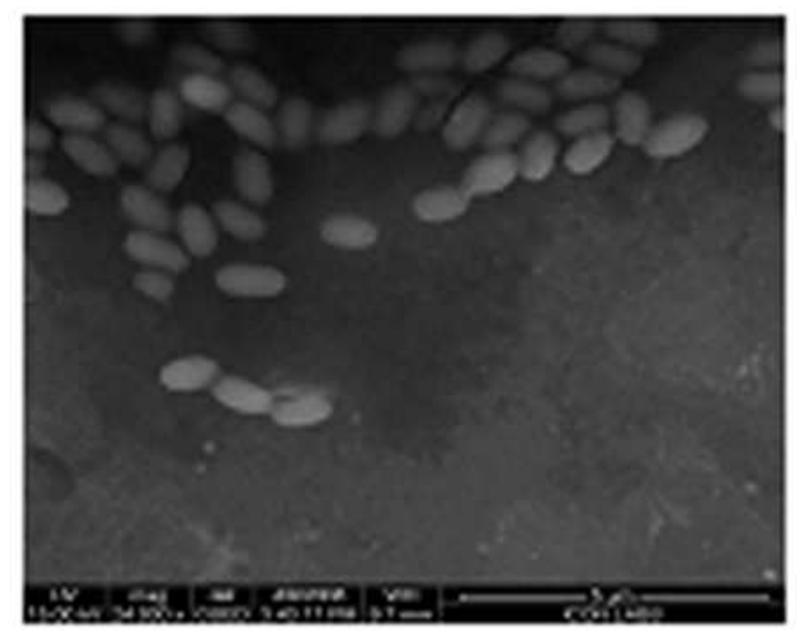

(e)

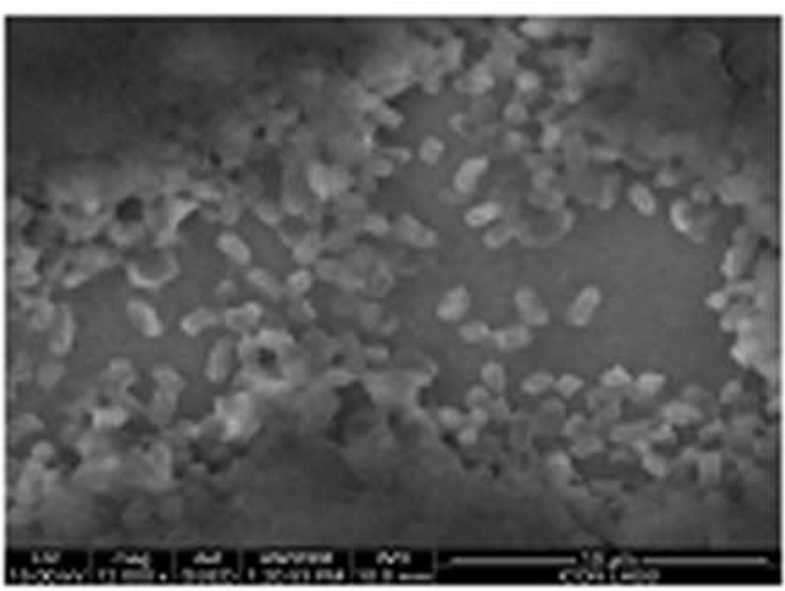

(b)

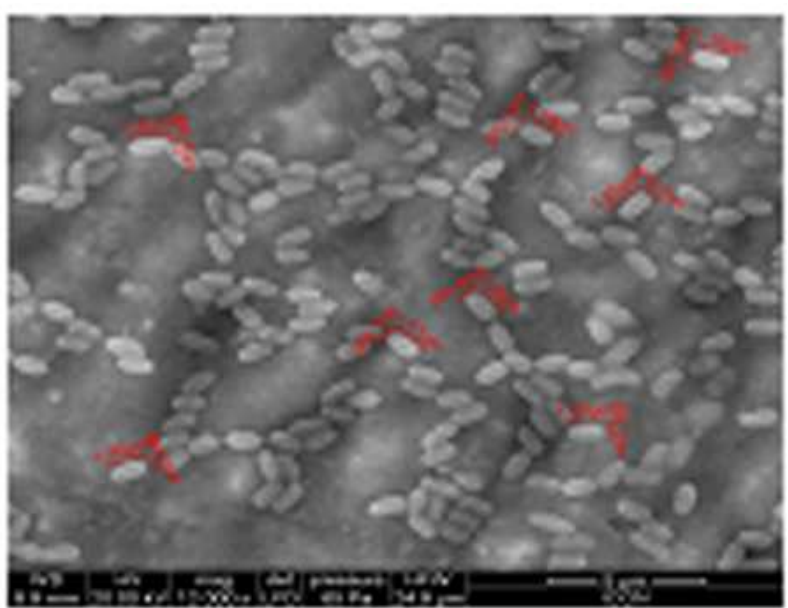

(d)

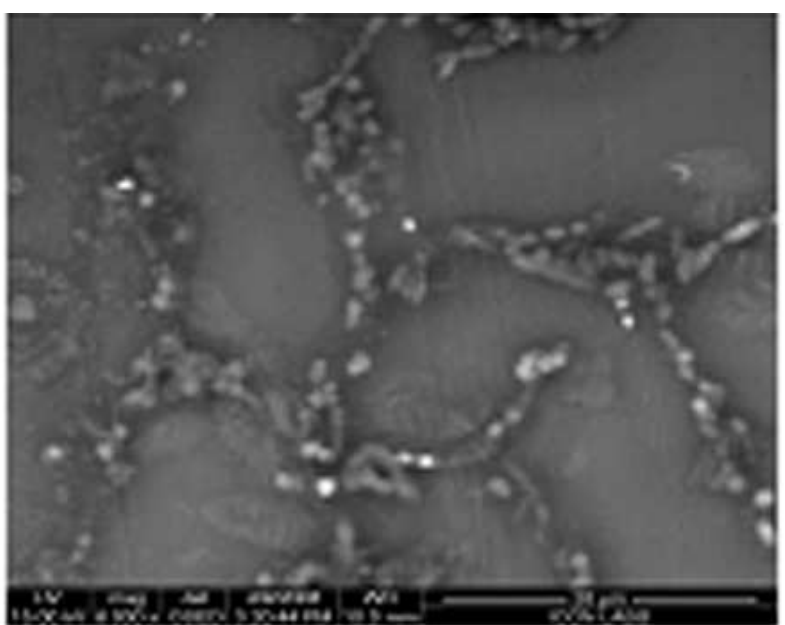

(f)

Fig. 1. Environmental scanning electron microscopic images of the marine isolates visualized using Environmental Scanning Electron Microscope (FEI QUANTA 200 MARK 2). (a-f) Represents the scanning electron micrographs of the six isolates at the following magnification:, SM2 (20,000X), SD1 (12,000X), SD2 (24,000X), SD3 (6000X), SD4 (24,000X) and SV1 $(12,000 \mathrm{X})$ respectively. Figure $\mathrm{a}, \mathrm{b}$ and $\mathrm{d}$ show distinct pilli like structure existing between cells 


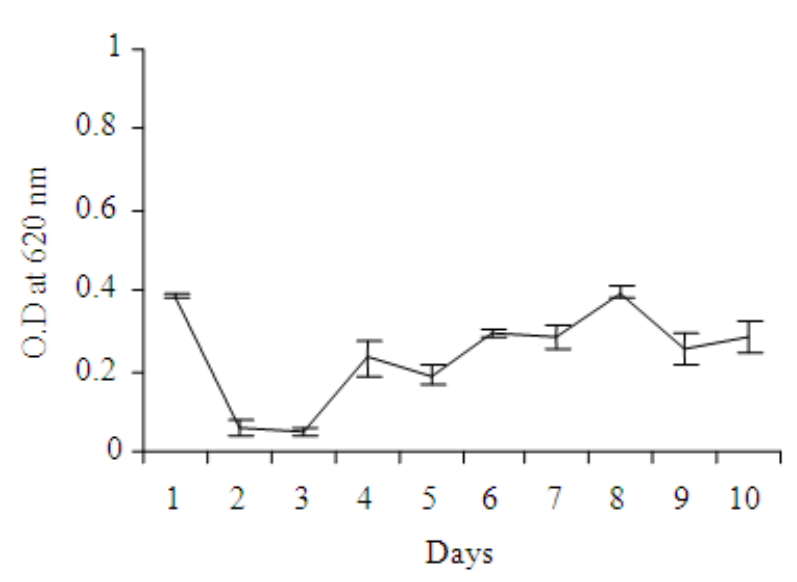

(a)

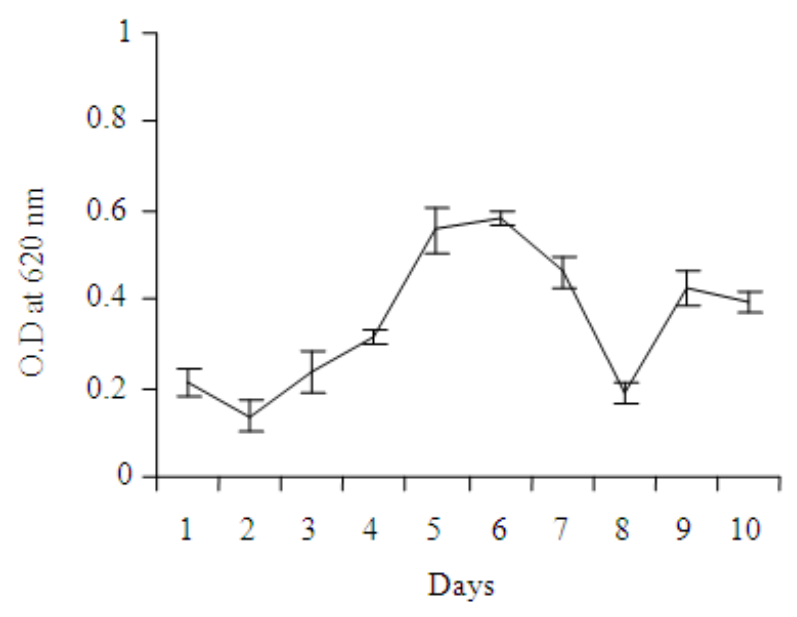

(c)

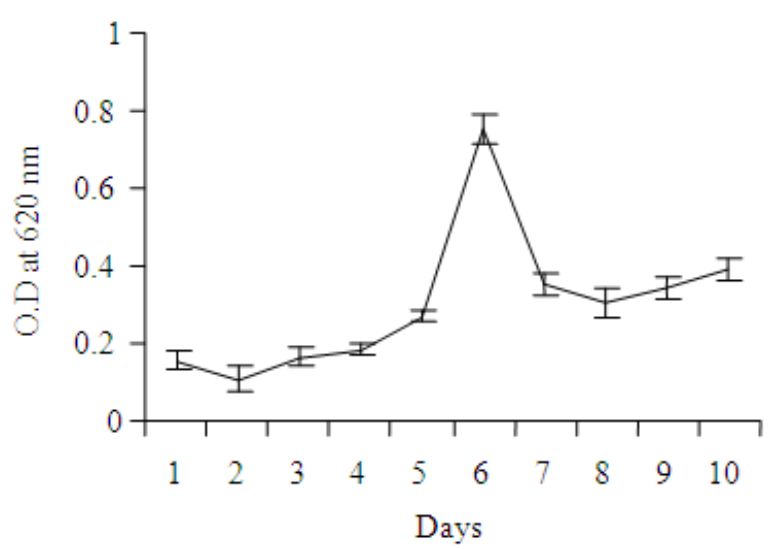

(e)

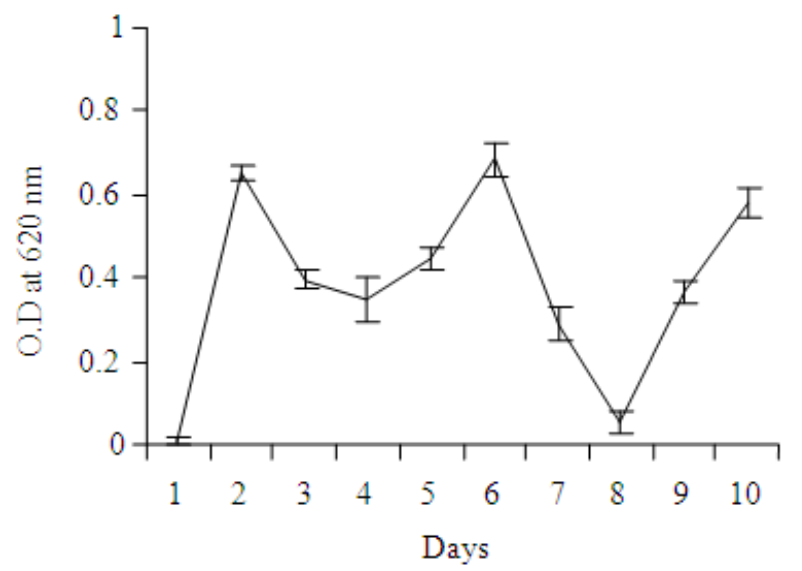

(b)

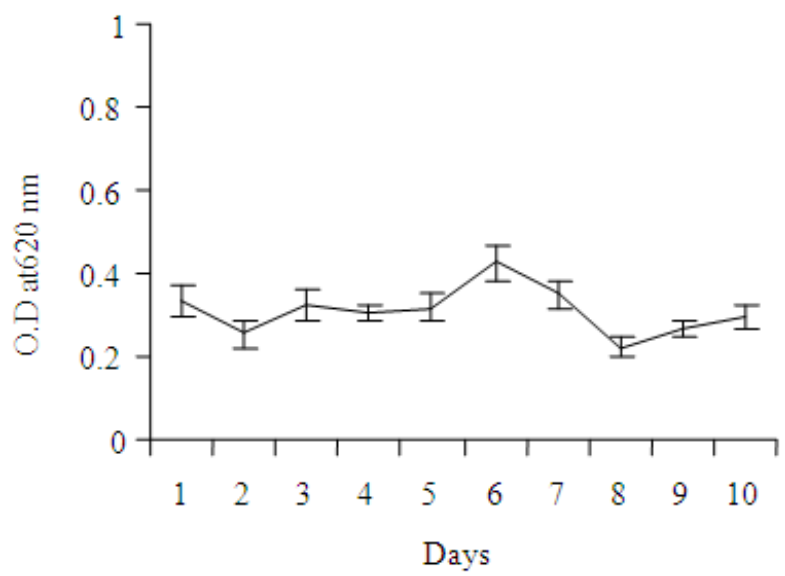

(d)

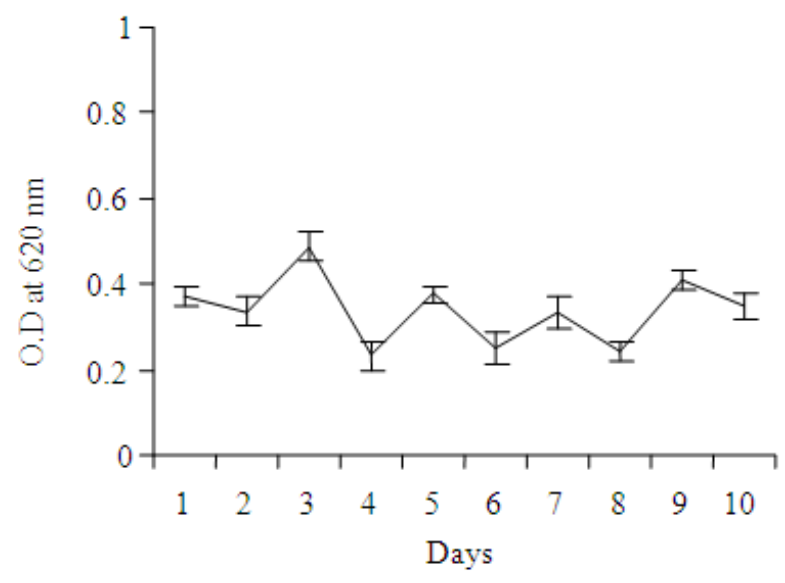

(f)

Fig. 2. Biofilm forming ability of the marine isolates. Figure depicting the biofilm forming abilty of marine isolates on polysterene plates as determined using standard crystal violet staining method followed by optical density measurement at $620 \mathrm{~nm}$. All of the strains showed good biofilm forming ability (O.D lies between 0.2-0.7) from the initial day, except for SD1, SM2 and SD4. The biofilm forming ability of SM2 and SD4 was observed from 4th and 5th day respectively. SD1 did not show any biofilm forming ability on the 1st day 


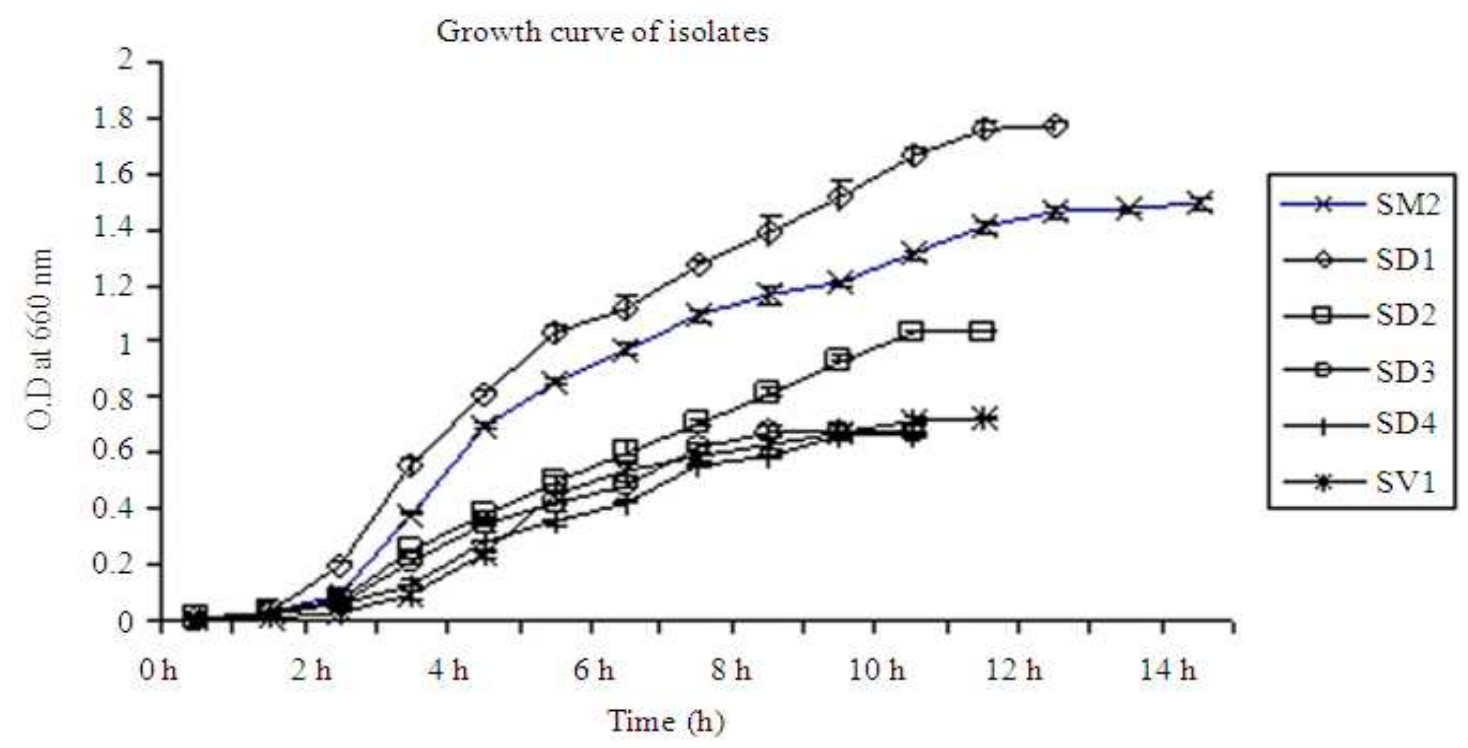

Fig. 3. Growth curve of the six isolates under optimum condition. Figure depicting the growth profile of the six isolates in enriched medium (LB broth). $1 \%$ inoculum was transferred to sterile LB broth from confluent overnight grown pure culture. At $0 \mathrm{~h}$ of incubation (immediately after adding the inoculum) the O.D was observed to be 0 . Then it was incubated under $150 \mathrm{rpm}$ shaking condition at $37^{\circ} \mathrm{C}$. At regular intervals of $1 \mathrm{~h}$, the growth was checked by measuring the Optical Density at $660 \mathrm{~nm}$ (Beckman UV-Vis spectrophotometer). SD1 and SM2 showed similar patterns of growth with stationary phase onset at the 11 th $\mathrm{h}$ of growth for the first isolate and at the 13th $\mathrm{h}$ for the second. SD2, SD3, SD4 and SV1 show similar growth patterns up to the 7th $\mathrm{h}$ of growth with stationary phase at the 8th $\mathrm{h}$ for isolates SD3 and SD4 and at 10th $\mathrm{h}$ for SV1 and SD2. This variation under optimum growth condition for the isolates points towards their varied identity at the molecular level

Table 2. Table representing the extent of metal accumulation within the cell of the isolates using EDXRF analysis

\begin{tabular}{llrrrr}
\hline Metal Conc. (in PPb) & Co & $\mathrm{Cr}$ & $\mathrm{Cu}$ & $\mathrm{Ni}$ & $\mathrm{Pb}$ \\
\hline SM2 & 1.51 & 11.04 & 7.00 & 0.2 & 36128.85 \\
SD1 & 2.89 & 9.09 & 0.68 & 0.95 & 13070.69 \\
SD2 & 2.83 & 5.98 & 34.80 & 0.68 & 3214.42 \\
SD3 & 0.46 & 10.04 & 20.82 & 7.84 & 4838.24 \\
SD4 & 0.50 & 4.13 & 57.90 & 0.30 & 5045.91 \\
SV1 & 0.60 & 0.80 & 3.47 & 1989.42 \\
\hline
\end{tabular}

Ceftazidime, Cf for Ciprofloxacin, Do for Doxycycline Hydrochloride, G for Gentamicin, Mt for Metronidazole, N for Neomycin, Nx for Norfloxacin, $\mathrm{Pb}$ for Polymyxin B, R for Rifampicin, Ro for Roxithromycin, $\mathrm{T}$ for Tetracycline, Tr for Trimethoprin, Va for Vancomycin. Intracellular accumulation of the isolates were measured for five common contaminant metals in parts per billion (ppb). It was found that the accumulation of lead within the cell was highest among all of the isolates.

\subsection{Molecular Characterization}

The partial 16S rDNA sequence analysis was done to reveal the molecular identity of the isolates. The phylogenetic trees were constructed using neighbour joining method. The partial $16 \mathrm{~S}$ rDNA sequence could only provide the identification at the genus level. Thus all the sequences being novel were submitted to GenBank, the accession numbers were FJ377718, FJ377719, FJ377721 to FJ377724 for SD2, SM2, SD1, SD3, SV1 and SD4 respectively (Table 1).

\subsection{Continuous Production of Enzyme by Immobilized Cells on Inert Matrix}

Protease and amylase productions were compared under different conditions of incubation at regular interval of $1 \mathrm{~h}$ for a total span of $12 \mathrm{~h}$. It was found that protease production was maximum from immobilized sheet, whereas the amylase production was maximum in shake flask culture (Fig. 4a and b). The bioreactors were recharged every $12 \mathrm{~h}$ and the protease production on sheet (Fig. 4c) reached the highest value after 3rd recharging maintained it till 8th recharging where after is was reduced to half (9th recharging) and maintained as such till the 20th recharge. But on immobilized hay protease production was maximum during 10th recharge and thereafter it slowly decreased till it reduced to half on the 17 th recharge. On immobilized sheet and hay the amylase production (Fig. 4d) reached highest value on 9th and 5 th recharging respectively. 


\subsection{Application of Protease \\ 3.9. Recovery of Precious Metal}

The effects of these proteases on exposed X-ray films were also checked after $48 \mathrm{~h}$ of incubation where except SD1 all other isolates exhibited complete removal of the gelatin layer (data not shown). This action has already been reported for proteases from different bacterial sources (Gupta et al., 2002). Silver impingement within the gelatin layer comes out with decomposed material which could be recovered further through different chemical methods.

The cells from culture containing metal strips that were washed only with PBS showed total accumulation (intracellular as well as adsorbed on the surface) whereas the other samples washed with $0.1 \mathrm{~N} \mathrm{HCl}$ followed by PBS only showed intracellular accumulation. The cell grown normally (i.e., in absence of metal strip) was also analyzed using EDXRF. EDXRF analysis results showed a qualitative difference in count for silver and gold accumulation within the bacterial cells. The actual metal accumulation within the cell was obtained by subtracting the accumulation of the metal within equal weight of untreated cell from that within treated cells. The cell grown in presence of gold and silver strip only showed silver accumulation. Total accumulation (after only PBS wash) of silver within cells grown in presence of gold and silver strips respectively were 874 and 2232 folds where as the same for intracellular accumulations were 320 and 572 respectively. Thus there was substantial adsorption of metal on the cell surface. But surprisingly in both cases only silver accumulation was visualized. There could be for two reasons, one that SM2 was not able to accumulate gold and second that the gold strip that was incubated was containing mostly silver. So it can be concluded that this strain could be used for testing of silver impurity in alloys.

SEM analysis also revealed the surface structure difference between treated and untreated gold and silver strips. The untreated strip surfaces were rough and uneven whereas the surface morphology of the treated samples were smooth. This would be due to leaching of silver from the metal surface of the strips by the isolated strain (Fig. 5). The detection of impurities by help of bacteria is environment friendly, but the drawback of this process is that it is much slower than other conventional processes.

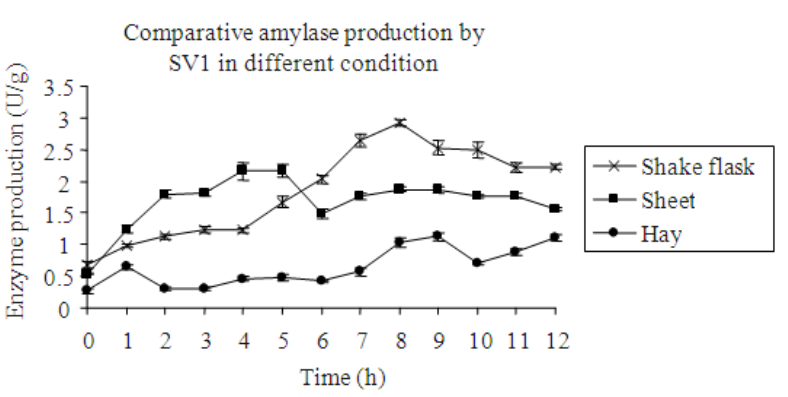

(b)

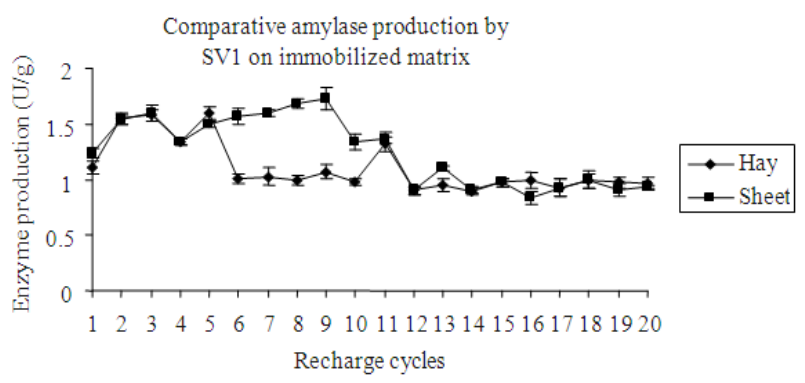

(d)

Fig. 4. Continuous enzyme production on immobilized matrix. At regular intervals of 1 hour, protease and amylase production on immobilized matrix (hay and sheet) were compared with shake flask culture (incubated at $37^{\circ} \mathrm{C}, 150 \mathrm{rpm}$ continuous shaking). ( $a$ and $b$ ) It was found that amylase production was maximum in shake flask culture, whereas the protease production was maximum on immobilized sheet. (c and d)A zig-zag pattern of enzyme (protease and amylase) production was found on both of the inert matrices 


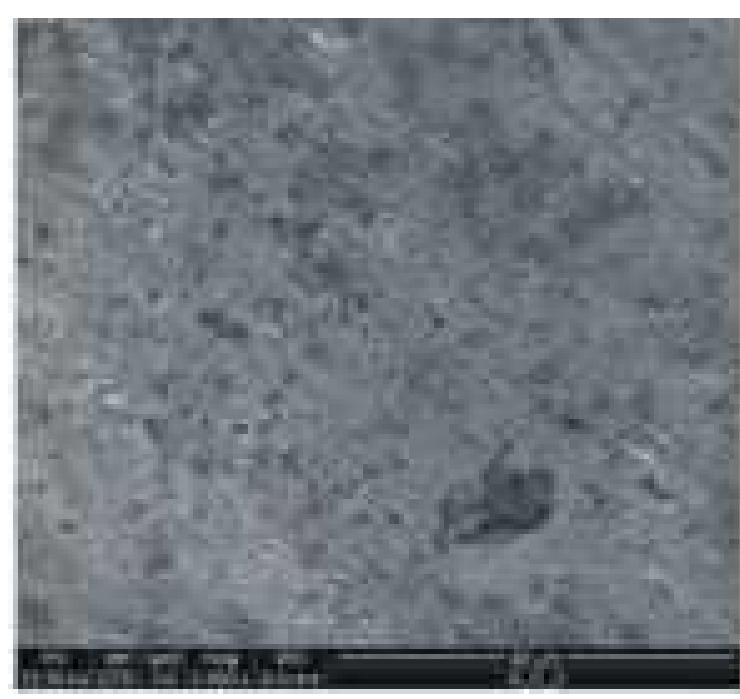

(a) Untreated gold plate

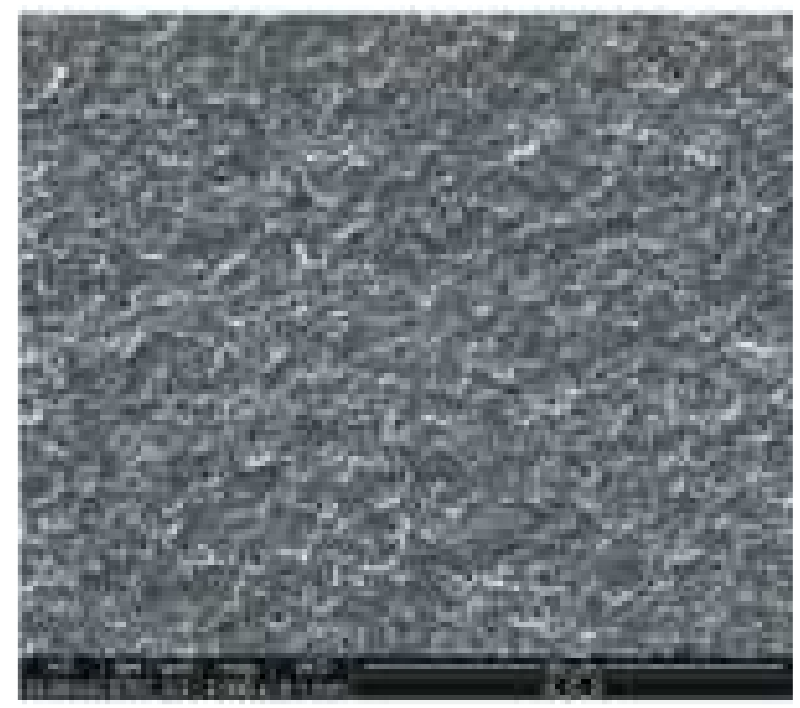

(c) Untreated silver plate

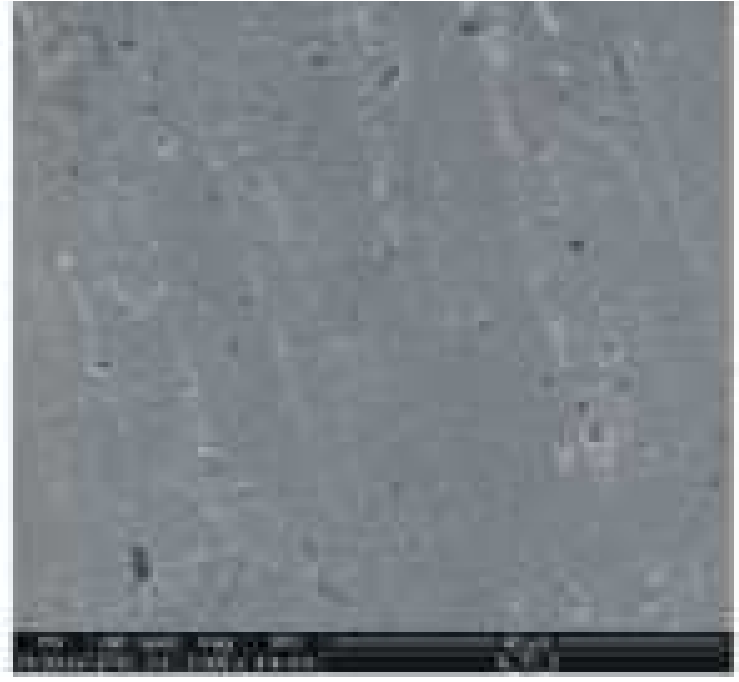

(b) Gold plate after treatment

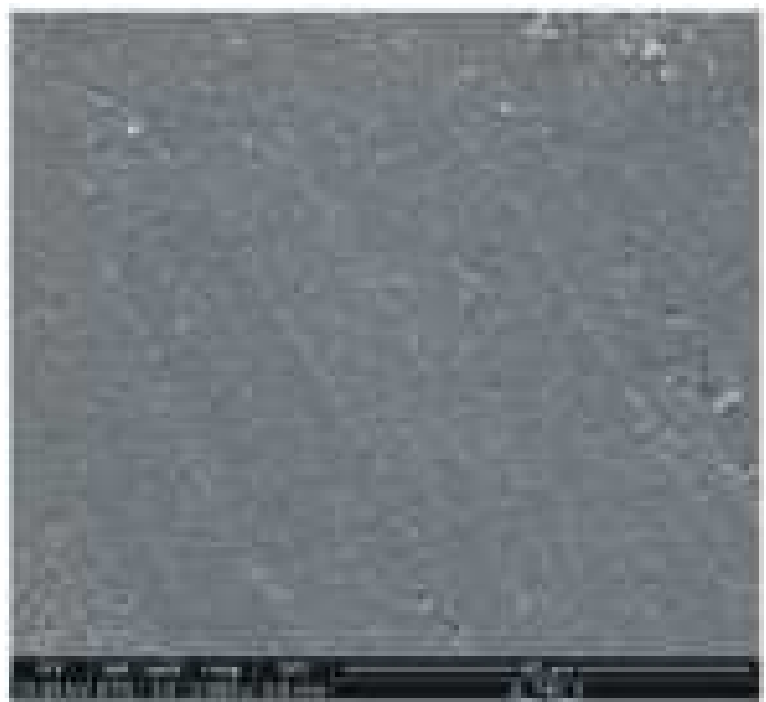

(d) Silver plate after treatment

Fig. 5. Scanning electron micrographic images of metal strips. Considering the heavy metal accumulating ability of SM2, the metal strips (zero valent state) of silver $(\mathrm{Ag})$ and gold $(\mathrm{Au})$ were dipped into two different set of SM2 culture and $1 \mathrm{ml}$ of $1 \mathrm{X} \mathrm{LB}$ was added into respective tubes. To sustain their growth $1 \mathrm{ml}$ of $1 \mathrm{X} \mathrm{LB}$ medium was replaced every 12 hours retaining the cells in each tube. This condition was maintained for 2 months. The strips were taken out, washed with distilled water, incubated in $1 \mathrm{ml}$ bleach for $15 \mathrm{mins}$ and again washed with distilled water thrice before drying. The surface of the strips was observed under SEM (FEI QUANTA 200 MARK 2 at $15 \mathrm{kV}$ ). (a and c) depicted a rough surface of untreated gold and silver strip. When it was treated with protease producing metal accumulating bacteria, the surface became smooth for both gold (b) and silver (d) strips

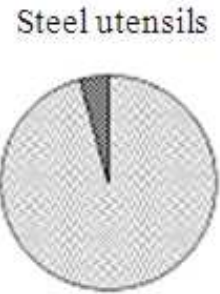

(a)

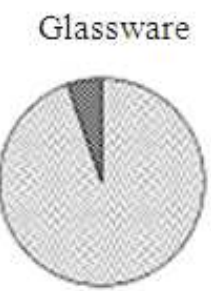

(b)
Kitchen

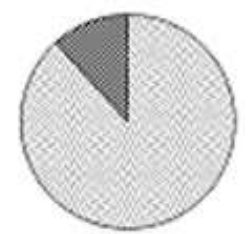

(c) 


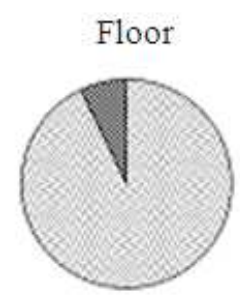

(d)

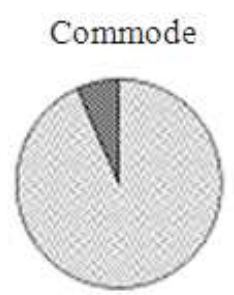

(e)

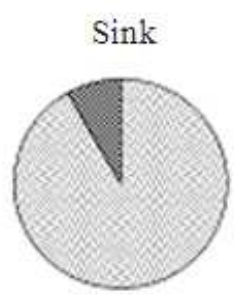

(f)

Fig. 6. Pie chart of the market survey of the modified detergent. The combination of SM2+SD2 was used as detergent additive for market survey. Cell free supernatant containing extracellular protease and lipase was concentrated by lyophilization (Heto Dry Winner, Maxy dry Lyo). Each gram of detergent was mixed with $6 \mathrm{U}$ protease and $2.25 \mathrm{U}$ lipase before air drying. The detergent with and without additive was then supplied to 50 different households to get a feedback on the wash performance efficiency as per the supplied questionnaire. Pie chart of steel utensil wash performance (a) revealed maximum acceptance (95.74\%) followed by $94.59 \%$ for glassware (b), 88.24, 92.86, 93.33 and $91.67 \%$ for the purpose of kitchen (c), floors (d), commode (e) and sink (f) cleaning respectively

\subsection{Wash Performance Analysis}

The microbial enzyme formulation using SM2 and SD2 showed better cleaning efficiency. The combined effect of protease and lipase as additive with detergent showed better result than detergent without additive. The enhanced efficiency was backed up by the market survey data.

The analysis report revealed acceptance in most of the household for various cleaning purposes (Fig. 6) with maximum acceptance for washing steel utensil $(95.74 \%)$ followed by glassware (94.59\%), washing floors (92.86\%) and WC (93.33-91.67\%) as well as kitchen cleaning $(88.24 \%)$. In most cases the modified detergent was needed in same if not less quantity as compared to the control detergent. This analysis indicated that the modified detergent would be industrially appreciated in large scale.

\section{CONCLUSION}

The complete characterization of the novel isolates revealed their $\mathrm{pH}$ and temperature tolerance, antibiotic and heavy metal response. The heavy metal accumulation by the isolates gives rise to the possibility of applying them in remediation of toxic metals. Either the single isolates or their mixed consortia can be applied for bioremediation. The protease secreting property definitely provides an additional advantage for using them as sources of commercial enzymes. The efficiency of proteases as an additive to detergent and X-ray film clearance could also be commercially exploited. Thus the biodiversity screening revealed the existence of biotechnologically important microbes from the coastal regions of India.

\section{ACKNOWLEDGEMENT}

The researchers acknowledge the support of the West Bengal University of Technology for the computational facility and the laboratories; University Grant
Commision-Inter University Consortium for the student fellowship as well as Department of Atomic Energy, Government of India under the BRNS scheme for financial assistance.

\section{REFERENCES}

Adarsh, V. K., M. Mishra, S. Chowdhury, M. Sudarshan and A.R. Thakur et al., 2007. Studies on metal microbe interaction of three bacterial isolates from East Calcutta Wetland. Online J. Biol. Sci., 7: 80-88. DOI: $10.3844 /$ ojbsci.2007.80.88

Andrykovich, G. and I. Marx, 1988. Isolation of a new polysaccharide-digesting bacterium from a salt marsh. Applied Environ. Microbiol., 54: 1061-1062.

Anto, H., U. Trivedi and K. Patel, 2006. Alpha amylase production by Bacillus cereus MTCC 1305 using solid-state fermentation. Food Technol. Biotechnol., 44: 241-245.

Arami, M., S. Rahimi, L. Mivehie, F. Mazaheri and N.M. Mahmoodi, 2007. Degumming of Persian silk with mixed proteolytic enzymes. J. Applied Polym. Sci., 106: 267-275. DOI: 10.1002/app.26492

Arpigny, J.L. and K.E. Jaeger, 1999. Bacterial lipolytic enzymes: Classification and properties. Biochem. J., 343: 177-183.

Baharum, S.N., E.K. Beng and M.A.A. Mokhtar, 2010. Marine microorganisms: Potential application and challenges. J. Biol. Sci., 10: 555-564.

Bull, A.T., A.C. Ward and M. Goodfellow, 2000. Search and discovery strategies for biotechnology: The paradigm shift. Microbiol. Mol. Biol. Rev., 64: 573606. DOI: 10.1128/MMBR.64.3.573-606.2000

De, J., A. Sarkar and N. Ramaiah, 2006. Bioremediation of toxic substances by mercury resistant marine bacteria. Ecotoxicology, 15: 385-389. DOI: 10.1007/s10646-006-0066-4 
George-Okafor, U.O and F.J.C. Obido, 2011. Purification and some properties of thermo-stable alkaline serine protease from thermophilic Bacillus sp. Gs-3. J. Biol. Sci., 11: 299-306.

Godfrey, S. and T. We, 1996. Industrial Enzymology. 2nd Edn., Nature Publishing Group, ISBN-10: 0333594649, pp: 624.

Gupta, R., Q.K. Beg and P. Lorenz, 2002. Bacterial alkaline proteases: Molecular approaches and industrial applications. Applied Microbiol. Biotechnol., 59: 15-32. DOI: 10.1007/s00253-0020975-y

Haefner, B., 2003. Drugs from the deep: Marine natural products as drug candidates. Drug Discov. Today, 8: 536-544. PMID: 12821301

Hameed, A., T. Keshavarz and C.S. Evans, 1999. Effect of dissolved oxygen tension and ph on the production of extracellular protease from a new isolate of bacillus subtilis $\mathrm{K} 2$, for use in leather processing. J. Chem. Technol. Biotechnol., 74: 5-8. DOI:

10.1002/(SICI)10974660(199901)74:1<5::AID-JCTB979>3.0.CO;2-T

Harayama, S., Y. Kasai and A. Hara, 2004. Microbial communities in oil-contaminated seawater. Curr. Opin. Biotechnol., 15: 205-214. DOI: 10.1016/j.copbio.2004.04.002

Haygood, M.G., E.W. Schmidt, S.K. Davidson and D.J. Faulkner, 1999. Microbial symbionts of marine invertebrates: Opportunities for microbial biotechnology. J. Mol. Microbiol. Biotechnol., 1: 3343. PMID: 10941782

Karunakaran, E. and C.A. Biggs, 2011. Mechanisms of Bacillus cereus biofilm formation: An investigation of the physicochemical characteristics of cell surfaces and extracellular proteins. Applied Microbiol. Biotechnol., 89: 1161-1175. DOI 10.1007/s00253-010-2919-2

Kumar, D., Savitri, N. Thakur, R. Verma and T.C. Bhalla, 2008. Microbial protease and application as laundry detergent additive. Res. J. Microbiol., 3: 661-672.

Kwon, K.K., H.S. Lee, S.Y. Jung, J.H. Yim and J.H. Lee et al., 2002. Isolation and Identification of biofilmforming marine bacteria on glass surfaces in dae-ho dike, Korea. J. Microbiol., 40: 260-266.

Malathu, R., S. Chowdhury, M. Mishra, S. Das and P. Moharana et al., 2008. Characterization and wash performance analysis of microbial extracellular enzymes from East Calcutta Wetland in India. Am. J. Applied Sci., 5: 1650-1661. DOI: 10.3844/ajassp.2008.1650.1661

Manivasagan, P., G. Rajaram, S. Ramesh, S. AshokKumar and P. Darmotharan, 2011. Occurance and seasonal distribution of antibiotic resistance heterotrpic bacteria and physio-chemical characteristics of Muthupettai mangrove environment, southeast coast of India. J. Environ. Sci. Technol., 4: 139-149.
Miranda, C.D and R. Rojas, 2006. Copper accumulation by bacteria and transfer to scallop larvae. Mar. Pollut. Bull., 52: 293-300. DOI: 10.1016/j.marpolbul.2005.08.022

O'Toole, G.A. and R. Kolter, 1998. nitiation of biofilm formation in Pseudomonas fluorescens WCS365 proceeds via multiple, convergent signalling pathways: A genetic analysis. Mol. Microbiol., 28: 449-461. DOI: 10.1046/j.1365-2958.1998.00797.x

Rao, M.B., A.M. Tanskale, M.S. Ghate and V.V. Deshpande, 1998. Molecular and biotechnological aspects of microbial proteases. Microbiol. Mol. Biol. Rev., 62: 597-635.

RayChaudhuri, S. and A.R. Thakur, 2006. Microbial DNA extraction from samples of varied origin. Curr. Sci., 91: 1697-1700.

Sattley, W.M., M.T. Madigan, W.D. Swingley, P.C. Cheung and K.M. Clocksin et al., 2008. The genome of Heliobacterium modesticaldum, a phototrophic representative of the Firmicutes containing the simplest photosynthetic apparatus. J. Bacteriol., 190: 4687-4694. PMID: 18441057

Shigemura, K., T. Shrikawa, H. Okada, K. Tanaka and S. Kamidono et al., 2005. Rapid detection and differentiation of Gram-negative and Gram-positive pathogenic bacteria in urine using TaqMan probe. Clin. Exp. Med., 4: 196-201. DOI: 10.1007/s10238004-0056-X

Sogin, M.L., H.G. Morrison, J.A. Huber, D.M. Welch and S.M. Huse et al., 2006. Microbial diversity in the deep sea and the underexplored "rare biosphere". PNAS, 103: 12115-12120. DOI: 10.1073/pnas.0605127103

Souza, M.J.D., S. Nair, P.A.L. Bharathi and D. Chandramohan, 2006. Metal and antibioticresistance in psychrotrophic bacteria from Antarctic Marine waters. Ecotoxicology, 15: 379-384. DOI: 10.1007/s10646-006-0068-2

Sudhakar, M., C. Priyadarshini, M. Doble, P.S. Murthy and R. Venkatesan, 2007. Marine bacteria mediated degradation of nylon 66 and 6. Int. Biodeter. Biodegr., 60: 144-151.

Tork, S., M.M. Aly and L. Nawar, 2010. Biochemical and molecular characterization of a new local keratinase producing Pseudomomanas sp., MS21. Asian J. Biotechnol., 2: 1-13.

Vignesh, S., A. Raja and R.A. James, 2011. Marine drugs: Implication and future studies. Int. Jr. Pharmacol., 7: 22-30. 